\title{
The Role and Potential Dangers of Visualisation when Learning about Sub-Microscopic Explanations in Chemistry Education
}

Ingo Eilks ${ }^{\star 1}$, Torsten Witteck ${ }^{2}$ And Verena Pietzner ${ }^{3}$

$\approx$ The core of theory-driven chemistry education consists of the constant shift between the different representational domains of chemical thinking: the macroscopic, the sub-microscopic, and the symbolic domains. Because the sub-microscopic domain can neither be seen nor directly visualised, it requires specific forms of visualisation, i.e. pictures and animations illustrating the model-based level of discrete particles, atoms, or molecular structures. This paper considers the central role visualisations play when learning about the model-based, sub-microscopic level, but it also reflects the dangers inherent in employing insufficiently examined, poorly considered, or even misleading visualisations. This is outlined using different examples taken from both textbooks for lower secondary chemistry education (for students aged 10 to 15) and from the internet. Implications for structuring and using sub-micro visualisations in chemistry education are also given.

Keywords: Chemistry education, Representational levels, Students' misconceptions, Visualisation

$1 \quad{ }^{\star}$ Corresponding author. University of Bremen, Germany ingo.eilks@uni-bremen.de

2 Engelbert-Kaempfer-Gymnasium, Lemgo, Germany

3 University of Hildesheim, Germany 


\section{Vloga in potencialne nevarnosti vizualizacije pri učenju submikroskopskih razlag pri pouku kemije}

Ingo Eilks*, Torsten Witteck And Verena Pietzner

$\approx$ Bistvo učenja kemije, ki temelji na teorijah, je sestavljeno iz nenehnega prehajanja med različnimi predstavitvami v kemijskem mišljenju: makroskopska, submikroskopska in simbolna raven predstavitve. Ker se submikroskopske ravni ne da videti niti si je ne moremo neposredno predstavljati, so potrebne specifične oblike vizualizacije, tj. slike in animacije, ki prikazujejo raven delcev; atomov ali molekul. Prispevek predstavlja ključno vlogo, ki jo ima vizualizacija pri učenju o submikroskopski ravni kemijskih pojmov. Opozarja pa tudi na nevarnosti uporabe nezadostno proučenih, slabo domišljenih ali celo zavajajočih vizualizacij. To je podkrepljeno $\mathrm{z}$ različnimi primeri iz učbenikov za učence med 10 in 15 letim starosti ter s primeri s spleta. Podani so tudi nekateri predlogi za uporabo submikroskopskih predstavitev pri pouku kemije.

Ključne besede: pouk kemije, ravni predstav, napačna predstava pri učencih, vizualizacija 


\section{The essential role of visualisation for teaching and learning chemistry}

Understanding the learning of science is today regularly referred to the theory of 'constructivism' (Bodner, 1986). From constructivism, we understand learning chemistry as students developing their knowledge and understanding within an active process of constructing new knowledge. This process is firmly based upon and connected to any prior knowledge and concepts that the learners possess. New information is processed in the foreground of the cognitive framework that pupils already have in their minds. All previously-existing information in the mind of the learner constantly influences any and all interpretation of newly-acquired information. The newly-constructed framework will emerge as a conglomerate of prior knowledge and any new pieces of information gained.

One of the major sources of students' pre-conceptions influencing their learning process is their everyday-life experience. Learners always try to initially apply their personal experiences when explaining newly presented phenomena, regardless of whether radically different concepts must be applied to gain a scientific reliable understanding (Pfundt, 1982). For example, everyone knows that a candle shrinks while burning. After combustion has ended, the candle is 'no longer there.' The candle has obviously disappeared (at least from the place where the candle originally was). An obvious conclusion based on everyday observation is that the wax in the candle disappeared due to something inherent in the process of combustion. Unfortunately, students over-generalise this interpretation, until they falsely conclude that all objects become 'lighter' and disappear during any processes of combustion (Pfundt, 1982).

Taking into account that chemistry not only describes phenomena, but also explains them with theory, a further problem emerges. Students often transfer their observations from the phenomenological macroscopic level to their understanding of the sub-microscopic level, the level of atoms and molecules. In the candle example above, students wrongly conclude that matter on the sub-microscopic level (atoms and molecules) can also 'disappear' completely, effectively a complete contradiction of the Law of Conservation of Mass and the Law of Conservation of Atoms. Modern science theorises that atoms and their constituent parts never disappear during chemical changes. Only this theory can explain why mass is always conserved and why the sub-microscopic entities involved in the combustion process never disappear. They can only change in certain, specific fashions. These two concepts in the learning process stand in direct contradiction to one another. For the neophyte student, the 
more familiar explanation (the one gained from everyday life experience) may hinder learning the scientifically accepted concept. This is why, based on the theory of constructivism, research into students' pre- and alternative conceptions have become a central focus of science education research (Wandersee, Mintzes, \& Novak, 1994).

Ever since early research on students' alternative conceptions in science education was published by Pfundt (1975) and Novick and Nussbaum (1978), curriculum developers throughout the world have plead for science teaching to take the alternative beliefs of students into account, when teaching science or developing new curricula and learning materials. One of the most popular ideas suggested by science education to overcome alternative conceptions has been the development of teaching strategies and materials that provoke a 'cognitive conflict' in the learner. The idea is to falsify naïve ideas by contrasting them with contradictory evidence, i.e. via experiments (Posner, Strike, Hewson, \& Gertzog, 1982). A cognitive conflict can then be used to promote conceptual change and to overcome naïve, not scientifically accepted ideas. An example for combustion is to observe the burning of iron wool. Iron wool becomes heavier during combustion because of the formation of solid iron-oxide.

Unfortunately, the use of cognitive conflict in connection with experiments and students' range of experience is limited to the phenomenological level. However, modern chemistry education also has to deal with the theoretical side of chemistry. Modern chemistry is characterised by interdependent, networked thinking in different representational domains. This consideration is in the core of Johnstone's (1991) famous contribution: 'Why is science difficult to learn?' Johnstone explained that learning and thinking in modern chemistry always take place in a constant shift between three different representational domains: the macroscopic, sub-microscopic, and symbolic domain (Fig. 1). If these three domains (including the accompanying levels between the macroscopic and sub-microscopic domains) and their interactions are misinterpreted, scientifically unreliable interpretations will necessarily emerge as a result (Eilks, Möllering, \& Valanides, 2007; Johnstone, 1991).

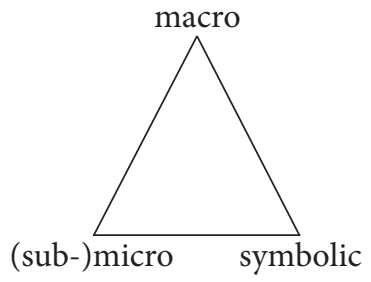

Figure 1. The 'Johnstone triangle' 
If there is a mismatch in students' thinking concerning the observable, macroscopic level, we may use a certain experiment to force the students into a cognitive conflict. Unfortunately, the same is not possible with the sub-microscopic domain in school-level chemistry courses. The necessary chemical and analytical technologies are neither available nor applicable in schools. Thus, the domain of sub-microscopic interpretations can hardly be touched upon by observations and experimental learning at the school level. Because of the invisible and non-tactile nature of the particle level, chemistry education deals with the sub-microscopic domain almost exclusively on a theoretical, model-based approach. Instead of phenomena and experiments, the use of models is believed to lead to a theory-based understanding at the sub-micro level. We use models to help us better understand phenomena at the sub-microscopic level. However, even the process of learning about models and using them correctly is a difficult task in itself (Justi \& Gilbert, 2002a, 2002b).

To aid the learning process on the sub-micro level, scientific models are used and illustrated using static (e.g. Brandt et al., 2001) or animated visualisations (e.g. Williamson \& Abraham, 1995). Such visualisations in a stable format are available in every textbook for secondary school chemistry. With advanced improvements in modern ICT, animated visualisations have also become readily available for teaching and learning. For example, computer-generated animations and simulations are now available on the internet for nearly every common topic within a typical chemistry curriculum.

Research suggests that the use of visualisation can foster students' learning of model-based explanations of the sub-microscopic world. Pictures, animations and simulations are powerful tools for teaching and learning chemistry. There is great potential in the use of these visualisations, because they help foster students' understanding of three-dimensional structures (Williamson \& Abraham, 1995), aid in developing learners' spatial abilities (Barnea \& Dori, 1999), provide a resource for reducing students' misconceptions about basic chemical principles (Kozma \& Russel, 2005b; Sanger \& Greenbowe, 2000; Yang, Greenbowe, \& Andre, 2004), and increase students' motivation when learning about chemistry (Tsui \& Treagust, 2004). Ardac and Akaygun (2005) as well as Stieff (2011) or Plass et al. (2011) showed that students could perform better when working with dynamic visualisations, in comparison to working with static visualisations. The study of Noh and Scharmann (1997) indicated that instruction with visualisations of the molecular level can help students to construct more scientifically correct conceptions. The positive effect of dynamic visualisations could be increased when the students have to create their own drawings based on them (Zhang, 2011). Niaz and Robinson (1993) stated that the ability of students to visualise is 
important in solving conceptual problems. Levie and Lentz (1982) summarised the research about the effects of static visualisations and pointed out that the use of text-redundant visualisations can not only help the learner to understand the text, especially when they are poor readers, but also can support learning by evoking affective reactions.

However, animated visualisations are believed to have decided advantages over static images (Mayer, 2003). Animated visualisations add details, which can support an understanding of the sub-microscopic world far beyond the potential of static pictures alone. They allow us to visualise the dynamic nature of the sub-microscopic world and can lead to a better understanding of the underlying chemistry concepts involved (Sanger \& Greenbowe, 2000; Williamson \& Abraham, 1995; or Kozma \& Russell, 2005a, 2005b; Yang, Greenbowe, \& Andre, 2004). However, static visualisations are more readily available, i.e. in typical textbooks, and can more easily be copied by the students into their notebooks.

At any rate, there are also hindering factors reducing the principally positive potential of static or animated visualisations when learning chemistry. Such negative aspects include an inadequate demand for the use of meta-cognitive competencies (Azevedo, 2004; Schwartz, Andersen, Hong, Howard, \& McGee, 2004), discounting a lack of students' prior knowledge (Shapiro, 1999), overestimating learners' ability to recognise and use proper spatial relations (Lee, 2007), and not taking into account limited learner attention spans when viewing animations (Ploetzner, Bodemer, \& Neudert, 2008), or the need of the learners to make relations between the symbols used in the visualisation and the chemical concepts they represent (Jones, Jordan, \& Stillings, 2005). However, this is the case in any other field of learning.

In summation, we recognise promising potential in the use of static and animated visualisations or graphically presented simulations for teaching and learning chemistry. However, this potential is not self-evident (Schnotz \& Bannert, 2003). Beyond the generally positive potential of graphics in the classroom, the danger also exists that visualisations themselves may hinder or even sidetrack the learning process (Eilks, 2003; Hill, 1988). Students may remember properly what they have seen in an animation and can make appropriate drawings, but they will not necessarily understand what they have seen (Kelly \& Jones, 2007). Learning through visualisations is based on a semantic process that only can lead to successful learning if it is properly related to the prior-knowledge of the learner (Schnotz \& Bannert, 2003) and portrays the scientific concept in a correct way (Hill, 1988). Therefore, if effective learning is expected to take place by using visualisations in science education, these visual aids need to be structured under consideration of the learner's prior knowledge concerning the respective 
topic or theory. The relationship between the scientifically accepted explanation, the sub-microscopic model chosen for the task, and the modelled nature of the explanation itself must be taken into account (Eilks, Witteck, \& Pietzner, 2009, 2010). Additionally, the visualisations in textbooks often only focus on the details of experiments, but not the scientific process and inquiry that are behind the experiments, which would help the learner to understand the aim of the experiment (Niaz, 1998).

To make the last thought more explicit, we should briefly touch upon two opposing points of view, which are somewhat self-evident, and may even lead us further in our discussion:

1) If the learner's preconceptions are scientifically reliable, illustrations should confirm, foster and strengthen them.

2) If the learner's preconceptions of a topic are scientifically unreliable, illustrations should induce a cognitive conflict which leads to overcoming the formerly-held ideas.

In both cases, all illustrations need to be scientifically reliable in the foreground of the applied level of theory. They should not demonstrate or call upon incorrect or conflicting explanations.

\section{The potentially misleading character of visualisations of the sub-microscopic domain, from textbooks and the internet}

Coming from the abovementioned theoretical reflections, the role of potentially misleading illustrations shall be discussed along with an analysis of illustrations from German chemistry and physics textbooks, and animations from the internet (e.g. Eilks, 2003; Eilks et al., 2009, 2010). The field of interest to be scrutinised in this paper is understanding the states of matter and dissolution. Both of these topics are quite typically found in nearly every curriculum for early lower secondary school chemistry or science lessons.

Research on students' understanding of the central concepts of science is a long-standing tradition. One of the most intensely researched topics has long been students' understanding of the particulate nature of matter. Since the 1970s (Novick \& Nussbaum, 1978), large quantities of research evidence has been made available for this topic. Studies have been performed that investigate students' alternative conceptions, how they are related to understanding the states of matter, which changes take place between them, and what types of sub-microscopic, model-based explanations are given for them (e.g. Garnett et al., 1995). The importance of this research for improving the teaching of science 
has been widely acknowledged (e.g. Taber, 2001b). Government standards for teacher training have also been instituted, requiring prospective teachers to be aware of the existing evidence on learners' alternative conceptions and to take it into account when they teach (Taber, 2001a).

Regardless, there still seems to be widespread failure in translating and disseminating such outcomes about students' alternative conceptions into practice, which is also the case in many other fields of science education (Costa, Marquez \& Kempa, 200o; de Jong, 2000). Moreover, research has also indicated that teachers and teacher trainees themselves often exhibit alternative conceptions in their thoughts and actions, which are similar (or even identical) to their students' conceptions (Goodwin, 2000; de Jong, 200ob; Valanides, 2000a, $2000 b)$. It has also been frequently observed that even curriculum developers and textbook authors do not always take sufficient care to carefully incorporate important research evidence when preparing teaching and learning materials (Eilks, 2003; Eilks, Möllering, \& Valanides, 2009).

Our examples looks at sub-microscopic visualisations taken from German lower secondary chemistry and physics textbooks for students aged 10 to 15, showing how they deal with the states of matter and dissolution. Secondary school chemistry education in German schools focuses beyond the phenomenological macroscopic level, aiming to offer explanations of and teaching on the sub-microscopic domain. When introducing the states of matter and their changes, students should acquire understanding and develop an internal image of the sub-microscopic world and how it can help us in understanding the macroscopic behaviour of matter and substances. Graphic representations are used because of the inaccessibility of the sub-microscopic domain to human senses. The visualisations are based on an initial, simple model of discrete particles. Central issues within this model include the existence of the particles themselves, their continuous movement, their average kinetic energy depending on the ambient temperature, and the forces and interactions between the particles.

Another central issue is the complete emptiness between the particles. This so-called 'horror vacui' is difficult for students to believe in, because it directly contradicts their macroscopic experiences. In the macroscopic world, there is always either air, water, or some other type of matter present between any two bodies (Novick \& Nussbaum, 1978). Every teacher knows the situation of asking students about the particulate nature of matter: 'What does water or air actually consist of?' Students frequently answer: 'Water consists of water particles, air consist of particles of oxygen and nitrogen, etc.' Yet a second question reveals the existing danger: 'But what is between the particles?' Very often the students consider water or air to be between the particles. In this case, water 
consists of water particles within a liquid water continuum (e.g. Johnson, 1998; Lee et al., 1993; Novick \& Nussbaum, 1978). Effectively, matter is simultaneously described as continuous and yet discontinuous.

The roots of the scientifically unreliable 'particles-in-a-continuum' interpretation by the students are clearly understandable. It is, however, more difficult to understand why chemistry textbooks often explicitly depict this continuous type of matter between the particles shown in their visualisations. Many textbook figures colour the empty space existing between particles, which is automatically interpreted in the pupils' imaginations as being either water or air. This continuum is often made blue for water and shows a surface, just like water in a beaker would have in a photograph. Figure 2 below is remarkable, mainly because of the blue background presented behind or between the particles. Figure 2a draws a direct parallel between the macroscopic phenomenon and the particle-based explanation, effectively mixing two separate domain levels together: the macroscopic and the sub-microscopic level. The graphics shown in Figure 2 have great potential for provoking or fostering in inexperienced students similar incorrect thinking that is not in line with chemical theory. The examples taken from these textbooks correlate directly with research evidence on students' potential misconceptions about water and any other types of liquids. Students often consider liquids to consist of different types of particles dissolved in water, e.g. water consists of water particles in liquid water, or alcohol consists of alcohol particles in a continuum of water (Stavy \& Stachel, 1985).
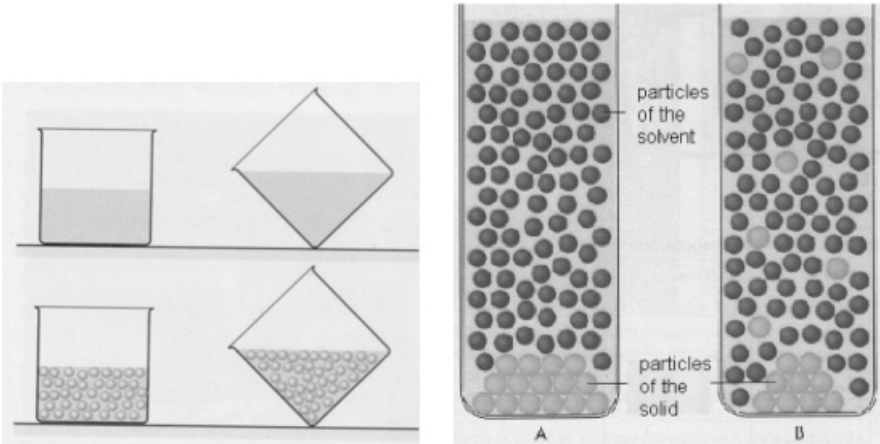

Figure 2. Model visualisation of liquids and dissolution: (a) connecting the macroscopic behaviour of a liquid to the sub-microscopic model explanation, with a liquid represented as if it were made up of particles within a blue continuum, implying that it would be the continuum causing the macroscopic 
behaviour (Kuhn, 1996), and (b) particles of the solvent shown in green, particles of the solid in yellow within a blue continuum showing that liquids are made by different particles 'dissolved' in a continuum (Tausch $\&$ von Wachtendonk, 1996).

Figure 2 also suggests that a liquid is made up of particles within a continuum. However, it also portrays a concept showing that the particles in a liquid might be spread from each other. This also is reported in research findings on students' alternative conceptions. Evidence has shown that students often have difficulties in correctly estimating and expressing the distances between particles in the different states of matter (Johnson, 1998). It seems quite easy for them to accept that particles in the solid state are packed closely to each other. Large particle distances in the gaseous state are also readily accepted, although the average distances in the gaseous state are very often perceived as being much smaller than they actually are. It is easy to see why many students consider particle distances in the liquid state as being somewhere in between those in the gaseous and solid forms. Sometimes pupils even use the arithmetic mean between these two states of matter to form their ideas of approximate inter-particle distances in liquids (Johnson, 1998). Figure 3 shows us a representation of just such a remarkable distance.

In Figure 4, the arithmetic mean is even explicitly suggested. However, to understand the phenomenological behaviour of substances in the liquid state, one of the most basic and essential ideas is the idea of incompressibility. This is important for any type of hydraulic applications of liquids. On the submicroscopic level, the incompressibility of liquids is caused by the fact that the distances between the particles are very small. There is no free room to move them much closer by external pressure. The particle distance in liquids is very near to the particle distances found in the solid state. Every scientifically coherent model representing the liquid state will thus avoid large gaps between the particles. The second important point in understanding phase changes in matter is that going from the solid to the liquid phase only requires minor changes in volume. The volume changes dramatically when going from liquid to the gaseous state, yet Figure 4 seemingly suggests that there is a major increase in particle spacing occurring during the melting process, which eventually ends in the over-inflated particle distances shown in the middle container. The given particle model-based visualisation used in this textbook suggests this interpretation has been scientifically proven and accepted by all teachers of science, thus giving it credence in the learner's eyes. Unfortunately, such an interpretation is a complete contradiction of the macroscopic behaviour of matter. 


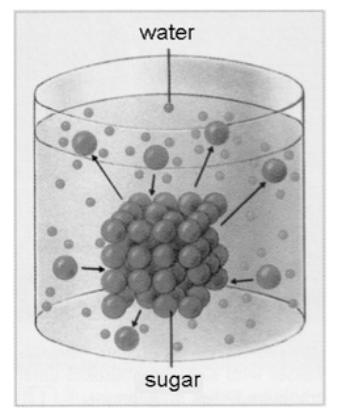

Figure 3. Dissolution: Water particles in blue, sugar particles in green, continuum in blue (Häusler \& Schmidkunz, 1996)

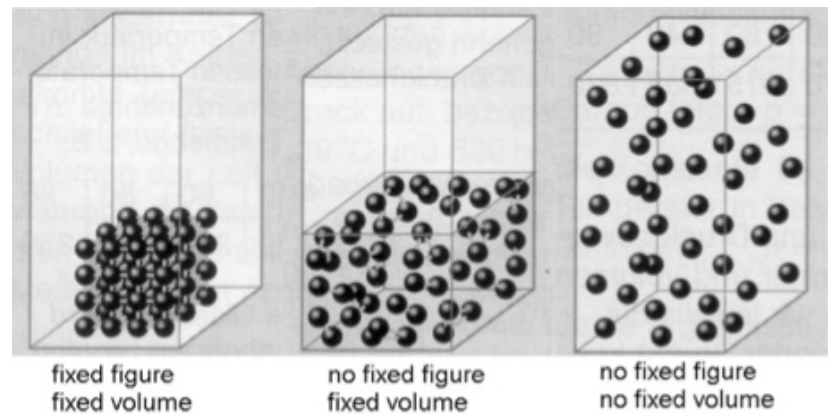

Figure 4. The three states of matter: spheres in black, continuum in blue (Bredthauer et al., 1993)

Figures $2 \mathrm{~b}$ and 3 also introduced a second, very common topic in initial chemical education curricula: dissolution. In introductory chemistry education, the topic of dissolution is normally also explained at the sub-microscopic level by using a simple model of discrete particles. Students often explain dissolution as the spreading of particles into the solvent continuum. In this case, the students sometimes neglect the particulate nature of the solvent itself (Andersson, 1990; Stavy \& Stachel, 1985). These ideas are also frequently found in textbooks, e.g. see Figure 5.

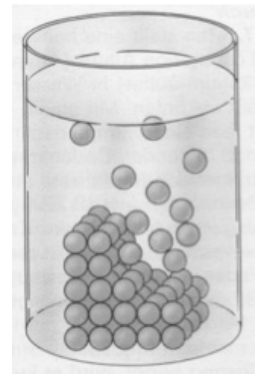

Figure 5. Dissolution - spheres of the solid in orange, continuum in blue (Fischer \& Glöckner, 1994) 
Discussing the illustrations presented here may help us illustrate exactly how students' thinking is affected by these visualisations. If the learners are not explicitly made aware that Figure 5 is a visualisation of dissolution on the sub-microscopic level, they can arrive at completely different, but very rational interpretations. In answering 'What will happen next?', some of our student teachers in different teacher training seminars mentioned that only particles from the very top of the 'crystal' are moving away. All of these particles also happen to be depicted moving upwards. The resulting interpretation was that small balls, like table tennis balls, are fixed to each other at the start, but are now moving away from each other. In the end, we might expect a carpet of balls on the surface of the liquid to form. Another interpretation was that bubbles of an orange gas are rising and will pop upon reaching the surface, like in sparkling water. Another interpretation was the distribution of bubbles from each other. The students were led to think that the bubbles will at some time pop within the liquid, thus leading to an orange-coloured liquid as the end result. All these interpretations are plausible and sound, in and of themselves. Unfortunately, they do not have anything in common with the commonly accepted, sub-microscopic model explanation of dissolution. The scientifically accepted theory is different. Theory does not consider dissolution to be driven by the solving substance or the particles of the solving substance. Dissolution is caused by the particle-particle interactions taking place between the particles of the solvent and the particles of the solute. These interacting forces and the free movement of the particles of the solvent cause the process of dissolution. If there are no solvent particles, a scientifically correct explanation is not possible using the visualisation presented in Figure 5.

Similar examples for confusing students with unsuitable visualisations can also easily be found in the internet. Figure 6 relates to several misconceptions from the literature on science education research. One misconception concerning the particulate nature of matter is pupils' understanding of particles within a continuum (Novick \& Nussbaum, 1978). We can see an explicit visualisation in the animation on the left. Students often do not accept that there is empty space between the particles. They consider the particles as being 'dissolved in air or water' (Johnson, 1998). Within this interpretation, the students consider water itself to consist of 'water particles' within a continuum of liquid water (Lee et al., 1993), see above. We can see this in the animated visualisation on the left: the particles are 'dissolved' in a grey continuum, which seems to belong to the water (in the solid and liquid state) without being defined in more detail. The particles later move into a continuum of air (or into completely empty space). 
Students often interpret macroscopic changes by describing them with similar changes occurring on the sub-microscopic level (Lee et al., 1993). Whenever matter is no longer visible after a chemical change, it seems to disappear, and they transfer this concept to the particles too (Osborne, Bell, \& Gilbert, 1983; Stavy, 1990). We can see this in the animated visualisation for evaporation shown on the left: The particles disappear after having left 'the liquid. Also, students sometimes have the idea that new substances or particles are formed during evaporation, ones which had not been part of the initial liquid (Osborne et al., 1983). This scientifically incorrect concept is portrayed in the right animation (lower picture): the water molecules are generated inside the bubbles within the boiling water. The same concept is visualised in the left picture: particles are continuously leaving the grey continuum without affecting the total number of particles 'in the liquid' or the grey continuum. Finally, students sometimes think that particles in the liquid state have considerable distances between them. The distance is often emphasised as being somewhat similar to the mathematical mean of the distances in the solid and the gaseous states (Garnett, Garnett, \& Hackling, 1995; Johnson, 1998). Just as we saw from the textbook illustrations, we can observe similar distances represented in both of the animated visualisations.

The figure clearly shows how these findings relate to two learning aids in the form of animations from the internet, including how they each visualise the alternative conceptions explicitly. Many other examples exist that specifically deal with commonly known alternative conceptions among learners for both this topic and for many other topics in the internet, e.g. Eilks et al. (2009, 2010) gave a detailed discussion of the mismatch still occurring between current research evidence and classroom materials prepared for visualisation of the Daniell voltaic cell. 


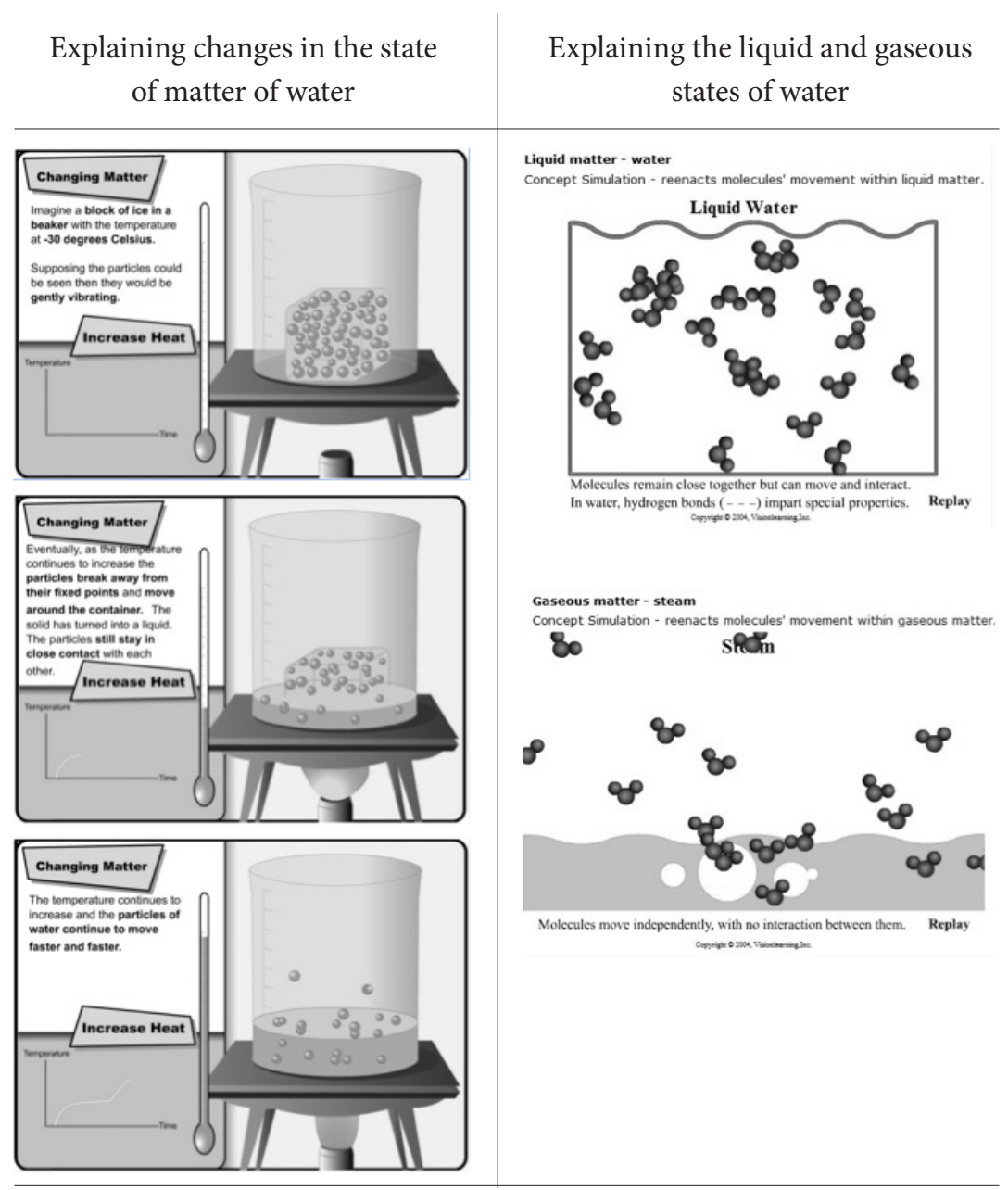

Figure 6. Animations of the states of matter and phase changes. The animations support the students in keeping alternate conceptions about the chemical concepts shown in the animations. (www.bgfl.org/bgfl/custom/resources_ftp/client_ftp/ks3/science/ changing_matter/index.htm and Carpi, A. (2004). 'Matter: States of Matter,' Visionlearning, CHE-3(1). www.visionlearning.com/library/module_viewer. php? mid $=120$. Both retrieved on November 01, 2008.)

While discussing animated internet visualisations of electrochemical cells in Eilks et al. (2009, 2010), we started our argumentation by referring to the time before WYSYWIG ('What you see is what you get') technology became established in the late 1980s. WYSIWYG was developed for real-time 
visualisation on the computer screen of work actively in progress. Until the shift towards WYSIWYG, text editors and graphic tools were unable to accurately depict materials on a computer screen and simultaneously alter them in realtime. Frequently, this led to various, unpleasant surprises when printing out a hard copy of the material after having changed it. Modern computer programs can correctly display fonts, page layouts or graphic elements on the computer screen, while simultaneously editing the respective documents, sometimes even in advance of making the changes.

After drawing this analogy, the question might similarly occur for both textbook illustrations and computer-based animated or static visualisations as discussed above: what is the result when students work with these tools? Constructivist learning theory (e.g. Bodner, 1986) says that information is not simply recorded by the learners, even when learning with visual stimuli. All information is filtered and then re-interpreted in the framework of the learner's prior conceptions. Using the terminology of ICT, learning is never a simple 'copy-paste' process. Therefore, when static or graphical visualisations are used in textbooks or by digital media, we might still be surprised by what the learner's mind produces after having learned with any visualisations.

The reason behind this is neglecting to maintain a thorough focus on the target group selected for the visualisations, in this case learners of initial chemistry. Textbooks and teaching aids on the internet are, in most cases, written by experts in chemistry. These experts know what exists behind the concept being employed. The experts know what the correct interpretation of the respective visualisation should be. For experts, just like the authors of textbooks and also most other teachers, these illustrations are easily understandable and may be helpful in supporting their imagination. High-level consumers are able to intentionally understand which model is being used, which domain level of representation is being referred to, and which aspects within the visualisation are (or are not) important. This is not the case for novices, such as students (Borges \& Gilbert, 1999; Coll \& Treagust, 2001; Jones \& Stillings, 2005; Taber, 2001b). The visualised content is not automatically understood and properly classified. This means that if a student is on the right path and working in a self-reflective manner, he or she will experience a cognitive conflict between the learned concept and the misleading visualisation. However, if the learner is insecure, uninformed or chooses the incorrect path of interpretation, incorrect ideas and/ or foreknowledge may be strengthened and confirmed in the wrong direction.

Textbook and media authors need to more thoroughly reflect upon the most effective pathways for visualising at the particle level in chemistry education. Research findings summarising students' alternative conceptions offer a 
helpful foundation for such reflection. Research evidence may help us determine whether an illustration actually expresses an alternative student conception and, thus, may actually be misleading. The same must also hold true for chemistry teachers who spontaneously portray the particle level on the blackboard. A concise knowledge of the alternative conceptions possibly existing in the heads of our pupils may lead us to a more sensitive, meaningful use of visualisations and help these illustrations do their proper job, just as we expect them to. This means helping students more easily understand and learn scientifically acceptable aspects of the particulate nature of matter. It also entails avoiding the construction of previously non-existent misconceptions in our learners and an avoidance of false reinforcement in the case of already existing false concepts (including carefully defusing such incorrect ideas).

Another far-reaching implication of the discussion above is scrutinising the mechanisms of curriculum development and teacher training. Because of the inaccessibility of the sub-microscopic level to direct human senses and its model-based character (e.g. Johnstone, 1991), chemistry teaching is reliant upon the use of different types of visualisations. From research findings, we know that explicitly dealing with models in science, and understanding their true nature is not an easy task. Neither the students (Grosslight, Unger, Jay, \& Smith, 1991) nor the teachers have a sufficient understanding of models and modelling in many cases (e.g. van Driel \& Verloop, 1999; Justi \& Gilbert, 2002a, 2002b; Sprotte \& Eilks, 2007). One of the main failures in using models to explain sub-microscopic phenomena in chemistry is frequent mixing of modelbased sub-micro level occurrences and the 'real world' phenomenological level. This is the reason that students and textbook authors are tempted to embed particles of water in a water continuum, both in their imaginations and in the visualisations discussed above. This means that both teachers and the authors of such learning materials first and foremost must develop a sufficiently elaborated understanding of scientific models and their use in their own minds. Taber (2008) plead for the development of a specific curriculum for teacher trainees that explicitly emphasised learning about models and modelling. This would develop not only teachers' content knowledge, but also expand their Pedagogical Content Knowledge (PCK) of models and modelling in science education (van Driel \& Verloop, 1999). We agree with this position. Additionally, this position might be connected thoroughly to specific elements of teacher training focusing students' development in Multiple Literacy with a focus on coping with the use of digital media in our today's world (Fehring, 2010). The above discourse, just like the one previously presented in Eilks et al. (2009, 2010), was started from many teacher training seminars showing that 
reflecting visualisations in the foreground of educational research on students' alternative conceptions, i.e. those that are obviously misleading, can sensitise student teachers and teachers to this problem and build up their skill in selfreflection and in analysing learning materials.

\section{References}

Andersson, B. (1990). Pupils' conceptions of matter and its transformation (age 12-16). Studies in Science Education, 18, 53-85.

Ardac, D., \& Akaygun, S. (2005). Using static and dynamic visuals to represent chemical change at molecular level. International Journal of Science Education, 27(11), 1269-1298.

Azevedo, R. (2004). Using hypermedia as a metacognitive tool for enhancing student learning? The role of self-regulated learning. Educational Psychologist, 40(4), 199-209.

Barnea, N., \& Dori, Y. (1999). High-school chemistry students' performance and gender differences in a computerised molecular modelling learning environment. Journal of Science Education and Technology, 8(4), 257-271.

Bodner, G. M. (1986). Constructivism - A theory of knowledge. Journal of Chemical Education, $63(10), 873-878$.

Borges, A. T., \& Gilbert, J. K. (1999). Mental models of electricity. International Journal of Science Education, 21(1), 95-117.

Brandt, L., Elen, J., Hellemans, J., Heerman, L., Couwenberg, I., Volckaert, L., \& Morisse, H. (2001). The impact of concept mapping and visualization on the learning of secondary school chemistry students. International Journal of Science Education, 23(12), 1303-1313.

Coll, R. K., \& Treagust, D. F. (2001). Learners' mental models of chemical bonding. Research in Science Education, 31, S., 357-382.

Costa, N., Marques, L., \& Kempa, R. (2000). Science teachers' awareness of findings from education research. Chemistry Education Research and Practice, 1, 31-36.

de Jong, O. (2000a). Crossing the borders: chemical education research and teaching practice. University Chemistry Education, 4(1), 29-32.

de Jong, O. (20oob). How to teach the concept of heat of reaction: A study of prospective teachers' initial ideas. Chemistry Education Research and Practice, 1, 91-96.

Eilks, I. (2003). Students' understanding of the particulate nature of matter and some misleading illustrations from textbooks. Chemistry in Action, (69), 35-40.

Eilks, I., Möllering, J., \& Valanides, N. (2007). Seventh-grade students' understanding of chemical reactions - Reflections from an action research interview study. Eurasia Journal of Mathematics, Science and Technology Education, 4(3), 271-286.

Eilks, I., Witteck, T., \& Pietzner, V. (2009). A critical discussion of the efficacy of using visual learning aids from the Internet to promote understanding, illustrated with examples explaining the Daniell voltaic cell. Eurasia Journal of Mathematics, Science and Technology Education, 6(2), 145-152. Eilks, I., Witteck, T., \& Pietzner, V. (2010). Using multimedia learning aids from the Internet for 
teaching chemistry - Not as easy as it seems? In S. Rodrigues (Ed.), Multiple Literacy and Science Education: ICTS in Formal and Informal Learning Environments (pp. 49-69). Hershey: IGI Global. Fehring, H. (2010). Multiple literacy in the ICT age: implications for teachers and teacher educators, an Australian perspective. In S. Rodrigues (Ed.), Multiple Literacy and Science Education: ICTS in Formal and Informal Learning Environments (pp. 180-206). Hershey: IGI Global.

Fischer, W., \& Glöckner, W. (1994). Stoff und Formel [Matter and formula]. Bamberg: C. C. Buchner. Garnett, P. J., Garnett, P. J., \& Hackling, M. W. (1995). Students' alternative conceptions in chemistry: A review of research and implications for teaching and learning. Studies in Science Education, 25, 69-95.

Goodwin, A. (2000). The teaching of chemistry: Who is the learner? ChemistryEducation: Research and Practice, 1, 51-60.

Grosslight, L., Unger, C., Jay, E., \& Smith, C. (1991). Understanding models and their use in science: conceptions of middle and high school students and experts. Journal of Research in Science Teaching, 28(9), 799-822.

Häusler, K., \& Schmidkunz, H. (1996). Elemente der Zukunft: Chemie [Elements of the future: chemistry]. München: Oldenbourg.

Hill, D. (1988). Misleading illustrations. Research in Science Education, 18, 290-297.

Jones, L. L., Jordan, K. D., \& Stillings, N. A. (2005). Molecular visualization in chemistry education: the role of multidisciplinary collaboration. Chemistry Education Research and Practice, 6(3), 136-149. Johnson, P. (1998). Progression in children's understanding of a 'basic' particle theory: a longitudinal study. International Journal of Science Education, 20(4), 393-412.

Johnstone, A. H. (1991). Why is science difficult to learn? Things are seldom what they seem. Journal of Computer Assisted Learning, 7(2), 75-83.

Justi, R. S., \& Gilbert, J. K. (2002a). Science teachers' knowledge about and attitudes towards the use of models and modelling in learning science. International Journal of Science Education, 24(12), $1273-1292$.

Justi, R. S., \& Gilbert, J. K. (2002b). Models and modelling in chemistry education. In J. K. Gilbert, O. de Jong, R. Justi, D. F. Treagust \& J. H. van Driel (Eds.), Chemical Education: Towards research-based practice (pp. 47-68). Dordrecht: Kluwer.

Kelly, R. M., \& Jones, L. L. (2007). Exploring How Different Features of Animations of Sodium Chloride Dissolution Affect Students' Explanations. Journal of Science Education and Technology, 16(5), 413-429.

Kozma, R., \& Russell, J. (2005a). Students becoming chemists: Developing representational competence. In J. K. Gilbert (Ed.), Visualization in science education (pp. 121-145). Dordrecht: Springer.

Kozma, R., \& Russell, J. (2005b). Multimedia learning of chemistry. In R. Mayer (Ed.), The Cambridge handbook of multimedia learning (pp. 409-428). New York: Cambridge University Press. Kuhn, W. (1996). Lehrbuch der Physik [Textbook of physics]. Braunschweig: Westermann Lee, H. (2007). Instructional design of web-based simulations for learners with different levels of 
spatial ability. Instructional Science, 35, 467-479.

Lee, O., Eichinger, D. C., Anderson, C. W., Berkheimer, G. D., \& Blakeslee, T. S. (1993). Changing middle school students' conceptions of matter and molecules. Journal of Research in Science Teaching, $30(3), 249-270$.

Levie, W. H., \& Lentz, R. (1982). Effects of text illustrations: A review of research. Educational Communication and Technology Journal, 30(4), 195-232.

Mayer, R. E. (2003). The promise of multimedia learning using the same instructional design methods across different media. Learning and Instruction, 13(2), 125-140.

Niaz, M., \& Robinson, W. R. (1993). Teaching algorithmic problem solving or conceptual understanding: Role of developmental level, mental capacity, and cognitive style. Journal of Science Education and Technology, 2(2), 407-416.

Niaz, M. (1998). From cathode rays to alpha particles to quantum of action: A rational reconstruction of structure of the atom and its implications for chemistry textbooks. Science Education, 82, 527-552. Noh, T., \& Scharmann, L. C. (1997). Instructional influence of a molecular-level pictorial presentation of matter on students' conceptions and problem-solving ability. Journal of Research in Science Teaching, 34(2), 199-217.

Novick, S., \& Nussbaum, J. (1978). Junior high school pupils' understanding of the particulate nature of matter: an interview study. Science Education, 62(3), 273-281.

Osborne, R. J., Bell, B. F., \& Gilbert, J. K. (1983). Science teaching and children's views of the world. European Journal of Science Education, 5(1), 1-14.

Pfundt, H. (1975). Ursprüngliche Erklärungen der Schüler für chemische Vorgänge [Original students' explanations of chemical phenomena]. Der Mathematische und Naturwissenschaftliche Unterricht, 28(3), 157-162.

Pfundt, H. (1982). Vorunterrichtliche Vorstellungen von stofflicher Veränderung [Pre-instructional imaginations of material change]. Chimica Didactica, 8, 161-180.

Plass, J. L., Milne, C., Homer, B. D., Schwartz, R. N., Hayward, E. O., Jordan, T., Verkuilen, J., Ng, F., Wang, Y., \& Barrientos, J. (2012). Investigating the effectiveness of computer simulations for chemistry learning. Journal of Research in Science Teaching, 49(3), 394-419.

Ploetzner, R., Bodemer, D., \& Neudert, S. (2008). Successful and less successful use of dynamic visualizations. In R. Lowe \& W. Schnotz (Eds.), Learning with Animation - Research Implications for Design (pp. 71-91). New York: Cambridge University Press.

Posner, G. J., Strike, K. A., Hewson, P. W., \& Gertzog, W. A. (1982). Accommodation of a scientific conception: Toward a theory of conceptual change. Science Education, 66(2), 211-227.

Sanger, M. J., \& Greenbowe, T. J. (2000). Addressing student misconceptions concerning electron flow in electrolyte solutions with instruction including computer animations and conceptual change strategies. International Journal of Science Education, 22(5), 521-537.

Schnotz, W., \& Bannert, M. (2003). Construction and interference in learning from multiple respresentations. Learning and Instruction, 13(2), 117-123.

Schwartz, N., Andersen, C., Hong, N., Howard, B., \& McGee, S. (2004). The influence of 
metacognitive skills on learners' memory of information in a hypermedia environment. Journal of Educational Computing Research, 31(1), 77-93.

Sprotte, J. A., \& Eilks, I. (2007). Introducing the particulate nature of matter - Results from a case study on experienced German Science Teachers' PCK of models and modelling. Paper presented at the 6th Conference of the European Science Education Research Association, Malmoe, Sweden.

Stavy, R. (1990). Children's conception of changes in the state of matter: from liquid (or solid) to gas. Journal of Research in Science Teaching, 30(3), 247-266.

Stavy, R. \& Stachel, D. (1985). Children's ideas about 'solid' and 'liquid'. European Journal of Science Education, 7, 407-421.

Stieff, M. (2011). Improving representational competence using molecular simulations embedded in inquiry activities. Journal of Research in Science Teaching, 48(10), 1137-1158.

Taber, K. S. (2001a). Constructing chemical concepts in the classroom: Using research to inform practice. Chemistry Education Research and Practice, 2, 43-51.

Taber, K. S. (2001b). Building the structural concepts of chemistry: some considerations from educational research. Chemistry Education Research and Practice, 2, 123-158.

Taber, K. (2008). Towards a curricular model of the nature of science. Science \& Education, 17(2-3), 179-218.

Tausch, M., \& von Wachtendonk, M. (1996). Stoff, Formel, Umwelt [Matter, formula, envrionment]. Bamberg: C. C. Buchner.

Tsui, C.-Y., \& Treagust, D. (2004). Motivational aspects of learning genetics with interactive multimedia. The American Biology Teacher, 66(4), 277-285.

Valanides, N. (2000a). Primary student teachers' understanding of the particulate nature of matter and its transformations during dissolving. Chemistry Education Research and Practice, 1, 249-262. Valanides, N. (200ob). Primary student teachers' understanding of the process and effects of distillation. Chemistry Education Research and Practice, 1, 355-364.

Van Driel, J. H., \& Verloop, N. (1999). Teachers' knowledge of models and modelling in science. International Journal of Science Education, 21(11), 1141-1153.

Wandersee, J. H., Mintzes, J. J., \& Novak, J. D. (1994). Research on alternative conceptions in science. In D. L. Gabel (Ed.), Handbook of research in science teaching and learning (pp.177-210). New York: Macmillan.

Williamson, V. M., \& Abraham, M. R. (1995). The effects of computer animation on the particulate mental models of college chemistry students. Journal of Research in Science Teaching, 32(5), 521-534. Yang, E.-M., Greenbowe, T. J., \& Andre, T. (2004). The effective use of an interactive software program to reduce students' misconceptions about batteries. Journal of Chemical Education, 81(4), 587-595.

Zhang, Z. H., \& Linn, M. C. (2011). Can generating representations enhance learning with dynamic visualizations? Journal of Research in Science Teaching, 48(10), 1177-1198. 


\section{Biographical note}

INGo EILKs, Prof. Dr., is a professor in chemistry education at the University of Bremen, Germany. His main research interests are Participatory Action Research in science education, cooperative learning, the socio-critical and problem-oriented approach to chemistry teaching, science teachers' pedagogical content knowledge and beliefs, and the development of modern chemistry curricula, teaching materials and textbooks.

Torsten WitTeck, Dr., is a grammar school teacher of Chemistry and Mathematics at the Engelbert-Kaempfer-Gymnasium, Lemgo, Germany. In 2006, he earned his PhD in chemistry education as a member of Ingo Eilks' Participatory Action Research group. The group was performing a study based on cooperative learning in chemistry education with special emphasis on the inclusion of multimedia tools and open experimentation tasks.

Verena Pietzner, Prof. Dr., is a professor of chemistry education at the University of Hildesheim, Germany. Her research interests include computer-based learning in chemistry, interdisciplinary learning, and the pedagogical content knowledge of chemistry teachers. 